\title{
Synergy Issues for Rhinoceros Conservation and Protection in Kenya
}

\author{
Joseph Muiruri Karanja and Kenichi Matsui
}

\begin{abstract}
The rhinoceros is endangered species in Kenya. Due to rampant poaching, the population of the black rhinoceros decreased from about 20,000 in the 1970s to about 300 in the early 1990s. Since then, its population increased to about 745 in 2018. From 2011 to 2015, however, about 160 rhinoceros were poached in Kenya. This paper examines the current status of rhinoceros protection and discusses how the protection regime can be improved in the future. We argue that inter-agency collaboration and public engagement are key to dismantle poaching cartels. These ideas can also facilitate the implementation of Kenya's Rhinoceros Action Plan. This paper explores collaboration opportunities at Lake Nakuru National Park by examining wildlife law enforcement as well as the investigation and prosecution of rhinoceros crimes. Here local communities are key stakeholders as they can help identify poachers and provide testimonies in courts. Inter-agency partnership through sharing of information and intelligence among law enforcement agencies, investigators, and prosecutors could promote both human and wildlife justice. Wildlife crimes involving endangered species could be prosecuted at the Environment and Land Court to expedite wildlife crime litigation. In the future, county environment courts may be established to better handle specialized prosecution of environment and wildlife crimes.
\end{abstract}

Index Terms-Endangered species, Lake Nakuru, poaching, rhino horn, wildlife conservation, wildlife crime.

\section{INTRODUCTION}

For decades, Kenya has attempted to curtail poaching activities by strengthening wildlife protection mechanisms, but it has achieved only limited success. Kenya has about 1,149 rhinoceros (of which 745 are black rhinoceros) [1]. The black rhinoceros (Diceros bicornis) is designated as critically endangered species in the IUCN Red List as well as in Kenya [2]-[4]. The white rhinoceros (Ceratotherium simum), another prominent rhinoceros species, is listed as near threatened species in the IUCN Red List [2]. In Kenya, it is designated as an endangered species [3].

Poaching has been the major threat to the survival of the rhinoceros [1]. The population of Kenya's black rhinoceros declined from about 20,000 in the 1970s to about 300 in the early 1990s. From 2006 to 2015, at least 213 rhinoceros were poached in Kenya. In 2013 alone, 59 rhinoceros were poached [5]. On March 20, 2018, the last male northern white rhinoceros died in Kenya. This leaves the sub-species at the

Manuscript received May 2, 2018; revised July 20, 2018

Joseph Muiruri Karanja is with the Graduate School of Life and Environmental Sciences, University of Tsukuba, Japan (e-mail: josentokaranja@gmail.com).

Kenichi Matsui is with the Faculty of Life and Environmental Sciences, University of Tsukuba, Japan (e-mail: kenichim@envr.tsukuba.ac.jp). edge of extinction given that the remaining two female species are infertile [6].

It has been a great challenge to crack down poaching cartels, as they are widespread but tight-knit global organizations. Past studies on wildlife crimes have emphasized the importance of establishing cross-jurisdictional and international collaboration efforts to dismantle poaching and illegal trafficking of wildlife products [7]-[10]. Source countries probably have the largest responsibility and opportunity to prevent poaching and trafficking through collaborative efforts. However, Kenya, a source country, faces formidable challenges to establish effective anti-poaching collaboration among key players like conservationists, researchers, law enforcement agencies, judiciary, public and media. This said, examining the possible outlook of national synergy could help better deal with wildlife crimes.

This paper examines how rhinoceros protection can be better formulated in Kenya at in-situ and ex-situ levels. At the conservation site (in-situ), it looks at how the Kenya Wildlife Service has attempted to coordinate rhinoceros protection at Lake Nakuru National Park. This Park is one of the most important protection sites as it is home to about 60 black and southern white rhinoceros. This Park, however, faces a unique challenge. Five seasonal rivers drain into Lake Nakuru. Therefore, although Lake Nakuru National Park is surrounded by an electric fence, the rivers can act as an entry route for the poachers. Recently, on July 31, 2018, a black rhinoceros was poached here. At the ex-situ level, collaboration has been sought under the relevant national law, such as conducting wildlife crime investigation, intelligence sharing and prosecution.

In the following discussion, we first illustrate the methodological approach utilized in the study. Then, we examine the evolution of the wildlife protection regime in Kenya to better understand the current protection status. Then we discuss in-situ and ex-situ protection conditions. Finally, the paper explores future collaboration opportunities in-situ and ex-situ situations.

\section{Methodology}

The study employed different approaches to explore collaboration opportunities for rhinoceros conservation and protection. We examined wildlife laws [3] and literature to understand the evolution of the rhinoceros protection regime in Kenya. Poaching data were acquired from the Kenya Wildlife Service reports, a poaching facts website and literature review. Information about wildlife crimes and their prosecution were mainly obtained from the Office of the 
Director of Public Prosecutions in Nairobi.

\section{KenYA's ANTI-POACHING POLICIES AND INSTITUTIONAL CHANGE FOR COLLABORATION}

The Kenyan government began its own efforts to protect rhinoceros as early as the late 1970s. In 1977 it banned trophy hunting partly to curb rampant poaching. It ratified the Convention on International Trade in Endangered Species of Wild Fauna and Flora (CITES) in 1979 [11]. However, the government lacked a sufficient institutional mechanism to prevent internal corruption and miscommunication among relevant agencies, allowing trafficking of rhinoceros horns possible even at Jomo Kenyatta International Airport and Mombasa Port [1]. Wildlife protection law enforcement was also lax and disorganized at Lake Nakuru National Park partly because most workers were not sufficiently trained to fight against poaching [12]. The situation somewhat improved with the establishment of the Kenya Wildlife Service in 1990, but stopping poaching remained to be extremely difficult tasks as rhinoceros horns had increasing demands and fetched high prices. Poachers and traffickers also became more sophisticated and organized [1], [12].

To curb prevalent poaching, Kenya established a rhino conservation program in 1985 . The program aimed at enhancing protection of rhinoceros through sanctuaries. In 1987, the first rhinoceros sanctuary was established in Lake Nakuru National Park. The program facilitated collaboration with private conservancies, NGOs and local communities to enhance wildlife law enforcement [13], [14].

In 2013, Kenya promulgated the Wildlife Conservation and Management Act to enhance law enforcement against wildlife crimes. The act increased maximum penalty for crimes related to poaching and trafficking rhinoceros horns from KES 40,000 (US\$ 400) to KES 20,000,000 (US\$ 200,000) and/or life imprisonment [3]. It empowered Kenya Wildlife Service to arrest, detain, and prosecute suspects. The Kenya Wildlife Service could now search land, premises, vessels, vehicles, aircrafts and trailers. They gained power to confiscate illegal wildlife trophies or materials. Partly as a result of this, the number of prosecuted wildlife crimes increased to $91 \%$ of the total arrests between 2013 and 2016 [15].

In implementing this tightened policy for years, Kenyan officials became more aware of the importance of inter-jurisdictional collaboration. As the 2013 Act also empowers law enforcement agencies like assistant warden and officer above the rank to act against wildlife crimes, law enforcement has increasingly required relevant agencies to coordinate and collaborate, for example, in searching vehicles and arresting people outside national parks [3]. As of August 2017, the Kenya Wildlife Service had only two prosecutors but, in the same year, it established partnership with Space for Giants, an NGO for big mammal protection in Kenya with close connection to the U.S. and U.K., to train new wildlife crime prosecutors. As a result, the Wildlife Service can now have at least 12 prosecutors [16].

In fighting against poaching and related activities, the Kenya Wildlife Service can also collaborate with the National Police Service, the National Intelligence Service, the Kenya Anti-Corruption Authority and the Office of Director of Public Prosecutions. They jointly investigate and prosecute suspects.

These joint efforts increased political support and public confidence in the prosecution of wildlife crimes. In 2016, for instance, Kenyan president spearheaded the action to burn 105 tons of ivory and 1.35 tons of rhinoceros horns, the largest amount of confiscated items in history [17]. This political demonstration, partly fueled by wide domestic and international media coverage, enhanced anti-poaching/trafficking sentiment among Kenyans and others. It also showcased Kenyan government's commitment to observing the national and international laws. The strong political support paved way for inter-agency collaboration among courts, legislators and administrators in strengthening the anti-poaching regime.

\section{IN-SITU SYNERGY FOR RHINOCEROS CONSERVATION AT LAKE NAKURU NATIONAL PARK}

Although the Kenya Wildlife Service has evolved and embraced technology and new partnerships to better address wildlife crimes, poaching methods and cartels' organization have evolved and advanced over time. Rhinoceros poaching and trafficking are largely organized crime. Poachers can be local communities living around national parks. They understand the local environment very well. If paid, some local people can host or inform non-resident poachers. Poachers are connected to middlemen. These middlemen purchase rhino horns from poachers. They utilize both public and private transport systems. The middlemen also provide logistics, intelligence and supplies. They deliver rhino horns to their patrons or kingpins [7], [18].

The kingpins have financial muscle and connections with key government officials and private sectors at transit points. They finance the poaching and trafficking network. They can ship the horns in both illegal and legal cargoes and fabricate exportation documents. At a destination country, they use the Internet and black markets to sell rhinoceros horns. Due to the sophisticated methods and networks, it is difficult to monitor, detect and predict trafficking routes [9], [18].

Poaching techniques changed over time. In the early 1970s and 1980s, rhino poaching occurred predominantly outside protected areas. Poachers mainly used firearms. When finding rhinoceros became difficult, poachers began to target protected areas, including Lake Nakuru National Park. Then snaring and poisoning (silent methods) became common [12], making it more difficult for rangers to detect [18].

In response to these new methods, the Kenya Wildlife Service has trained rangers and increased patrols within Lake Nakuru National Park. At all times, one ranger is stationed within each four-kilometer electric fence area. This fence is attached to the back-up solar powered grid system. The Park's rhinoceros are monitored daily. Their ears are notched for identification. In 2014, the Kenya Wildlife Service at Lake Nakuru National Park partnered with the World Wildlife Fund for Nature to insert microchips into rhinoceros bodies. Rhinoceros are now easily tracked, monitored and identified [19].

The Kenya Wildlife Service also has partnered with local 
ranchers and residents living around the Park to collect information about wildlife crimes. These local people sometimes tip the Service about potential poachers or intruders around the Park's boundaries. To enhance this communication and ensure timely response, the Wildlife Service has ten-digit toll free number (080059700). So far, many local people found this number difficult to memorize (ideally the Service may adopt three-digit toll free emergency number instead). Currently, people mainly report wildlife crimes by using National Police Service emergency numbers (999 or 112). We tried the above Police Service numbers, but they appeared to be usually busy. Sometimes it took us about 30 minutes to get through.

The Kenya Wildlife Service has celebrated Rhino Day (September 22) with support from local communities and celebrities. Rhino Day is to raise awareness about rhinoceros conservation and tourism promotion. At Lake Nakuru National Park, the Service invited Herman Kago, a famous comedian known us "Professor Hamo," and Michael Olunga, a professional footballer, in promoting "Cycle with Rhino" event. The Kenya Wildlife Service appointed Kago as rhino ambassador to assist in raising support for rhinoceros conservation [20].

\section{EX-SITU SYNERGY FOR RHINO PROTECTION}

\section{A. Law Enforcement, Investigation and Intelligence}

Collaboration is essential to effectively enforce wildlife laws and investigate wildlife crimes not only within a national park, where rhinoceros are protected, but also outside national parks, including port of entries. The Kenya Wildlife Service law enforcement unit works with other law enforcement agencies and communities to protect wildlife in Kenya at large [12].

Researches indicate that violent and property crimes decreased in Nakuru County after the National Police Service introduced community policing in 2009 [21]. This indicates there is collaboration opportunity between the Wildlife Service and the National Police Service as well as local communities to enhance community policing. Community policing has proved to be effective elsewhere. For instance, from 2011 to 2014, Nepal recorded zero rhinoceros poaching incidences following the introduction of the community policing system [22].

For community policing to work, the public must have faith in coordinating institutions like the Kenya Wildlife Service. In some situations, the Wildlife Service has been accused of extra-judicial killing, torture and disappearance of suspects. Such abuses are rarely investigated and prosecuted [23]. The local people would unlikely report poaching incidents to the Service with such distrustful past practices [10]. To improve the image of the Kenya Wildlife Service and gain support for community policing, the Kenya Wildlife Service internal training may focus also on public/community relations among Service personnel.

It has been often reported that poor security at seaports and airports facilitated the trafficking of wildlife products. Jomo Kenyatta International Airport in Nairobi and Kilindini Port in Mombasa are key transit routes [1]. At Jomo Kenyatta
International Airport, the wildlife-sniffing dogs are mobilized apart from custom control sniffing dogs, but many reports have confirmed that the Airport has much room for improvement in tightening its security [18]. In March 2017, for instance, about $112 \mathrm{~kg}$ of rhinoceros horns were confiscated at Noi Bai International Airport (Vietnam). These goods were shipped from Jomo Kenyatta International Airport [24]. Partly to deal with this weak security at the airport, the Manyani Training Field School has started training some at the Kenya Port Authority [12], [25].

The Kenya Wildlife Service also solicits for support from international organizations particularly to enhance its investigation and prosecution capacity. In November 2014 , for instance, the United Nations Office on Drugs and Crime (UNODC) organized "Recovering the Proceeds for Wildlife and Forest Crimes" workshop in Kenya. The workshop brought together 40 participants that included prosecutors, investigators, custom officials, the Kenya Revenue Authority, the judiciary and wildlife authorities for training. In the same year, UNODC signed a Memorandum of Understanding with Kenya to establish the Container Control Program to prevent illegal trafficking and smuggling via seaports [26]. Also, African Wildlife Foundation supported the Kenya Wildlife Service to strengthen its Canine Unit at Jomo Kenyatta International Airport [18].

\section{B. Prosecution and Judicial System}

Until recently most of poachers who were arrested for wildlife crimes were not brought to court. For instance, no court cases regarding rhinoceros horns and ivory trafficking were reported in Mombasa County between 2008 and June 2013 even though a large number of contrabands was seized there [27]. In the same period, only about $4 \%$ of wildlife crime suspects were convicted for a jail term. In 2014, out of 1,430 suspects for wildlife crimes only five were related to rhinoceros poaching and trafficking [28]. In 2013 and 2014, however, 59 and 35 rhinoceros were poached respectively [5].

Corruption among law enforcement officials has obstructed law enforcement. Regarding trafficking elephants and rhinoceros, about $60 \%$ of the offenders were found guilty from 2008 to 2013 , but only less than $7 \%$ was sentenced for a jail term. The rest received fines [27]. About $11 \%$ of elephant and rhinoceros cases were dismissed by magistrates or withdrawn by prosecutors. The offenders were discharged allegedly due to lack of evidence, missing case files, incomplete investigation and/or lack of preparation for the prosecution. The Kenya Wildlife Service rarely appealed [27]. Kahumbu et al. [27] showed that only poachers were convicted. We also found that although the Kenya Wildlife Service largely depends on sniffing dogs to carry out investigations and arrest suspects, canine evidence are partially admissible in court.

Wildlife case file mismanagement has been found deficient. From 2008 to mid-2013, about $70 \%$ of reviewed wildlife case files went missing [27] partly due to poor record keeping [10], [27]. Kenya's Judicial Transformation Framework (2012-2016) tried to adopt the electronic filing system and digitize court records and proceedings. The judiciary has started adopting text message-based inquiry to 
inform parties and people about the status of their cases. In early 2018, pilot studies launched at a few courts [29], [30].

Since 2011, Kenya has run the Environment and Land Court with the status of the High Court. Its decisions can be appealed to the Court of Appeal [31], [32]. Also, magistrate courts can hear environment and/or wildlife crime cases [32]. There are about 116 magistrate courts throughout the nation [33]. To enhance courts' capacity to deal with wildlife crimes, the Kenya Wildlife Service has collaborated with UNODC to educate some judges and magistrates more about wildlife crimes [26].

Accountability and integrity of the Judiciary are essential for wildlife justice. The corrupt judiciary can cripple community policing, law enforcement, investigation and prosecution efforts. The local communities, conservation agencies, law enforcement authorities, investigators, prosecutors and judges should all have a common goal of protecting wildlife [10]. In Kenya, the Judiciary Ombudsman provides a platform for the public to issue complains to address administrative justice in the Judiciary [33].

The wildlife cases are now prosecuted by the Office of Director of Public Prosecution. The Office has a specialized Environment and Wildlife Section [34] that facilitates collaboration between investigators and prosecutors. Prior to this, the Wildlife Service took prosecution tasks. Instead of prosecuting, the Service now provide evidence to the Public Prosecution Office.

In 2015, it established a wildlife forensics laboratory with support from the World Wildlife Fund for Nature (WWF), the United States Embassy in Kenya, the Canadian government and the East Africa Community [35]. The Kenya Wildlife Service also collaborated with the University of Pretoria and Jomo Kenyatta University of Agriculture and Technology to develop the Rhinoceros DNA Indexing System (RHoDIS) [36].

Finally, witness protection is not yet widely used for wildlife crimes although it is important to secure testimonies against serious and organized crimes, especially wildlife crime cartels [37]. The Kenya Witness Protection Agency was established in 2008 [38], but somehow the Kenya Wildlife Service has been excluded from the Witness Protection Advisory Board [38].

\section{CONCLUSION}

The 2013 wildlife law and institutional reforms have been a great impetus for the Kenya Wildlife Service to extend its anti-poaching works in collaboration with various agencies and international organizations. Before, wildlife law enforcement efforts were fragmented from prosecution efforts. Prosecution against wildlife crimes largely improved due to a better synergy and capacity building activities in the last five years. However, in the course of our research, we also found some more room for improvement in establishing an institutional synergy. For example, the Kenya Wildlife Service Intelligence Unit, the National Intelligence Service and the Wildlife Justice Commission can collaborate to conduct more expansive intelligence-based investigations about environmental crime cartels. Community policing could be further promoted to empower local communities for reducing poaching. Some liaison officers can enhance communication between the Kenya Wildlife Service and local tribes in sharing information about poaching. To bring more people to the anti-poaching side, a financial compensation scheme (e.g., for the witnesses) and witness protection can further motivate people to testify in court. The cases involving rhinoceros and other endangered species could be heard and determined by the Environment and Land Court. This may help expedite wildlife crime cases litigation. To enhance wildlife justice and win public confidence, the Kenya Wildlife Service and the judiciary should observe accountability and transparency.

\section{ACKNOWLEDGMENT}

We acknowledge generous support provided by the Kenya Wildlife Service for sharing some data and permitting us to carry out this research in Lake Nakuru National Park. We express our gratitude to the reviewers for their comments and suggestions that further improved this research.

\section{REFERENCES}

[1] S. Weru, "Wildlife Protection and trafficking assessment in Kenya: Drivers and trends of transnational wildlife crime in Kenya and its role as a transit for traffiked species in East Africa," TRAFFIC, ISBN no: 978-1-85850-386-8, Cambridge, United Kingdom, pp. 1-46, , 2016.

[2] International Union for Conservation of Nature (IUCN). (2017). The IUCN Red List of Endangered Species. [Online]. Available: www.iucnredlist.org

[3] Wildlife Conservation and Management Act (2013), Kenya Gazette Supplement no. 181 (Acts No.47), 2013.

[4] Kenya Wildlife Service. (September 26, 2017). World Rhino Day Commemorated. [Online]. Available: http://www.kws.go.ke/content/world-rhino-day-commemorated

[5] Poaching Facts, "Rhino poaching statistics: Kenya," Poaching Statistics, 2018.

[6] N. Komu, "Sudan world's last white male northern rhino, dies at O1 Pejeta in Laikipia," Daily Nation, March 20, 2018.

[7] A. S. Akella and C. Allan, "Dismantling wildlife crime: Executive summary," World Widlife Fund, Washingston DC, pp. 1-15, 2012.

[8] CMI and U4, "The resource bites back: Entry-points for addressing corruption in wildlife crime," Chri. Michelsen Institute (CMI) and Anti-Corruption Resource Centre (U4), 2016.

[9] G. Pink and R. White, "Collaboration in combating environmental crime - Making it matter. In environmental crime and collaborative state intervention," Palgrave Macmillan, London, pp. 3-19, 2016.

[10] UNODC, "Wildlife and forest crime analytic toolkit. United Nations Office on Drugs and Crime," UNODC, Vienna, pp. 1-196, 2012.

[11] CITES, "List of Contracting Parties: Kenya," 2017.

[12] D. Karanja, "The role of the Kenya wildlife service in protecting Kenya's wildlife," George Wright Forum, vol. 29, no. 1, pp. 74-80, 2012.

[13] E. O. Odada, J. Raini, and R. Ndetei, "Lake Nakuru: Experience and lessons learned brief," World Lakes, pp. 1-50, 2006

[14] B. O. Ouma, "Population performance of black rhinoceros (Diceros bicornis michaeli) on six Kenyan Rhino Sanctuaries," M.S. thesis, University of Kent, United Kingdom, 2004

[15] Office of the Director of Public Prosecutions, "New act leads to reduction in wildlife crimes," Nairobi, 2016.

[16] Capital News Correspondent, "Space for giants pledges support for special KWS prosecution unit," Capital News, August 25, 2017.

[17] AWF, “African landscape. Issue 2," African Wildlife Foundation $(A W F)$, Nairobi, Kenya, 2016.

[18] D. Gumbo, D. Wakukoya, Q. J. J. Thompson, L. Escot, L. Slobodian, M. G. Kisusi, N. Gichohi, P. Muruthi, and S. Pelle, "Strengthening legal mechanisms to combat wildlife crime," Wildlife Judicial and Prosecutorial Assistance Trainings Series, Bagamoyo, Tanzania, May 24-26, 2016.

[19] WWF, "Defending Kenya's Rhinos," World Wildlife Fund for Nature (WWF), 2014.

[20] Daily Nation, "Comedian professor hamo appointed as Lake Nakuru's rhino ambassador," Daily Nation, May 24, 2017. 
[21] M. Mwaniki, "The role of community policing in crime prevention: Kirinyaga County, Central Kenya," M.Sc. thesis, Mount Kenya University, Kenya, 2016.

[22] WWF, "How Nepal got to zero poaching," World Wildlife Fund for Nature (WWF), 2015.

[23] Amnesty International, "Kenya: Establish Commission of Inquiry into Violations by security agencies," December 10, 2016.

[24] Vietnam net, "Over 100kg of suspected rhino horn seized in Hanoi," March 14, 2017.

[25] Kenya Wildlife Service, "KWS Law enforcement academy," 2018.

[26] UNODC, "Global programme for combating wildlife and forest crime," United Nations office on Drugs and Crimes (UNODC), Vienna, pp. $1-28,2014$.

[27] P. Kahumbu, L. Byamukama, J. Mbuthia, and O. Drori, "Scoping study on the prosecution of related crimes in Kenyan courts," Wildlife Direct, Nairobi, Kenya, pp. 1-28, 2014.

[28] E. Gitari et al., "Outcome of court trials in the first two years of implementation of the Wildlife Conservation and Management Act, 2013," Wildlife Direct, Nairobi, Kenya, pp. 1-32, 2016.

[29] J. Wakaya, "Judiciary focuses on digitization to quicken dispensation of justice," Capital News, January 5, 2018.

[30] M. Maina, "Digitizing legal education in Kenya," Jurist, November 13 , 2012.

[31] Environment and Land Court Act (2011), "Laws of Kenya No. 19 of 2011," National Council for Law Reporting.

[32] Constitution of Kenya (2010), "Laws of Kenya," National Council for Law Reporting.

[33] Judiciary, "The Judiciary of Kenya," 2018.

[34] Office of the Director of Public Prosecutions, "Department: Offences Against the Person," 2016.
[35] S. Karanja, "Wildlife forensics lab opened in Nairobi," Daily Nation. May 8, 2015.

[36] WWF, "ARP supports bilateral initiative on DNA forensics to fight rhino crimes," World Wildlife Fund for Nature (WWF), 2012.

[37] K. Kramer, "Witness protection as a key tool in addressing serious and organized crime," Fourth GG Seminar, 2010

[38] Witness Protection (Amendment) Act (2016), "Act No. 45 of 2016 of the Republic of Kenya."

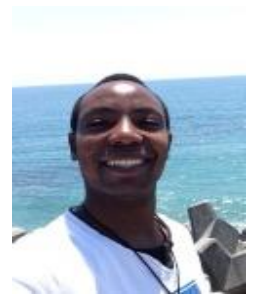

Joseph Muiruri Karanja is a $\mathrm{PhD}$ student at the Graduate School of Life and Environmental Sciences, the University of Tsukuba, Japan. His research interests include environmental governance, wildlife conservation, community participation, and wetland ecosystems. He earned a master's of science in Sustainability from the United Nations University, Japan, in 2015. In 2012, he graduated with bachelor's degree in disaster management and international diplomacy from the Masinde Muliro University of Science and Technology, Kenya.

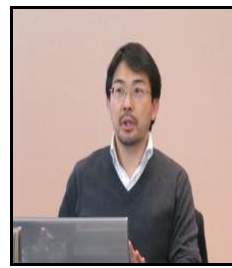

Kenichi Matsui is associate professor at the Faculty of Life and Environmental Sciences, the University of Tsukuba, Japan. He has taught at the University since 2008. In 2003, he obtained his $\mathrm{PhD}$ from the University of British Columbia, Canada. He received his master's from Arizona State University in 1996. His main research fields are water rights, water ethics, water governance, indigenous knowledge/ rights, biodiversity policies, and environmental dispute resolutions. 